Zeszyty Naukowe Szkoły Głównej Gospodarstwa Wiejskiego w Warszawie

Problemy Rolnictwa Światowego tom 18 (XXXIII), zeszyt 1, 2018: 248-262

DOI: $10.22630 /$ PRS.2018.18.1.23

Jacek Strojny ${ }^{1}$

Uniwersytet Rolniczy w Krakowie

\title{
Wzrost pobudzany eksportem czy eksport stymulowany wzrostem sektora rolnego
}

\section{Growth Led by Exports or Exports Driven by Agricultural Sector Growth}

\begin{abstract}
Synopsis. Celem opracowania jest analiza współzależności między międzynarodową wymianą produktami rolno-żywnościowymi a poziomem produkcji rolnej w wybranych krajach UE. Badanie oparto na metodologii analizy kointegracyjnej i modelach wektorowej autoregresji (VAR). Znaczenie ekspansji eksportowej dla wzrostu produkcji rolnej jest odmienne w poszczególnych krajach UE. W Polsce produkcja rolna jest kształtowana w znacznej mierze poziomem eksportu, ale pozostaje także pod wpływem własnej tendencji rozwojowej. Polski eksport rolno-spożywczy jest kształtowany własną tendencją rozwojową. Dla Francji nie wykryto współzależności między produkcją rolną i eksportem rolno-żywnościowym. Z drugiej strony, eksport jest kształtowany własną tendencją rozwojową i zidentyfikowano zależność między eksportem i produkcją rolną. Podsumowując, w Polsce eksport wspiera produkcję rolną, a we Francji wysoki poziom produkcji sektora rolnego stymuluje eksport.
\end{abstract}

Słowa kluczowe: analiza kointegracyjna, modele VAR, produkcja rolna, eksport rolno-żywnościowy

\begin{abstract}
The aim of the article is to analyze the interrelationship between the international exchange of agri-food products and the level of the agricultural production in selected EU countries. The study is based on cointegration analysis methodology and employs vector autoregression models (VAR). The relevance of export expansion for the growth of agricultural production differs in individual EU countries. Agricultural production in Poland has a lot to do with the level of the exports, but it is under the influence of its own developmental tendency, as well. The Polish agri-food exports are shaped heavily by their own trend. No interrelationship was detected between agricultural production and agri-food exports in France. On the other hand, exports are influenced by their trend and additionally a strong impact of the level of agricultural production on exports was detected. To conclude, exports support agricultural production in Poland, and the high level of production of the agricultural sector stimulates exports in France.
\end{abstract}

Key words: cointegration analysis, VAR models, agricultural production, agri-food exports

JEL Classification: C32, C39, N50, Q17

\section{Wstęp}

Na politykę proeksportową można spoglądać wąsko - w ramach ograniczającej się do sfery handlu zagranicznego polityki handlowej bądź szerzej w ujęciu normatywnym jako jeden $\mathrm{z}$ aspektów polityki gospodarczej zorientowany na osiagnięcie celów wzrostowych w pewnych dziedzinach aktywności gospodarczej. Zwiększenie dochodu narodowego

\footnotetext{
${ }^{1}$ dr hab., Katedra Statystyki i Ekonometrii UR w Krakowie, Al. Mickiewicza 21, 31-120 Kraków,
} e-mail: rrstrojn@cyf-kr.edu.pl,https://orcid.org/0000-0003-4632-8645 
(jakiego innym sposobem nie można uzyskać) w oparciu o strategię proeksportową predysponuje ją do klasyfikacji raczej w ramach polityki gospodarczej niż w kategoriach polityki handlowej (Rynarzewski i Zielińska-Głębocka, 2006). W tym ujęciu rozwój ekspansji eksportowej nie jest celem nadrzędnym, lecz sposobem osiągnięcia przyspieszenia rozwoju gospodarczego. Tradycyjnie polityka handlowa pojmowana jest w kategoriach kształtowania handlu zagranicznego przez władze ekonomiczne państwa (Mundell, 1961), co ma na celu ochronę krajowej produkcji i zatrudnienia oraz zagwarantowanie pożądanego poziomu bilansu płatniczego. Niektórzy autorzy wskazuja, że w obecnych warunkach systemy ekonomiczne winny funkcjonować w oparciu o kompleksową i spójną politykę gospodarczą. W ewoluującej rzeczywistości ekonomicznej działania ograniczające się do polityki handlowej polegającej na selektywnej interwencji państwa w obszarach eksportu oraz importu już nie sprawdzają się (Michałek, 2002).

Kompetentnie wdrażana polityka proeksportowa postrzegana jest jako czynnik przyspieszania zrównoważonego rozwoju gospodarczego. W tym ujęciu rozwojowi eksportu nadaje się znaczenie porównywalne $\mathrm{z}$ tradycyjnymi czynnikami wzrostu jak: praca, kapitał i zasoby. Poprzez rozprzestrzenianie się impulsów wzrostowych na inne gałęzie w ekspansji eksportowej można upatrywać równocześnie źródeł rozwoju całej gospodarki, co dokumentują liczne opracowania teoretyczne (Rosati, 1990). Strategia taka była realizowana po drugiej wojnie światowej przez wiele krajów, które osiagnęły wysokie tempo wzrostu gospodarczego. Strategia proeksportowa była stosowana zarówno przez kraje słabiej rozwinięte, jak i rozwinięte gospodarczo. W krajach wysoko rozwiniętych eksport stał się czynnikiem przeciwdziałania słabnącemu tempu wzrostu gospodarczego. $\mathrm{Z}$ jednej strony literatura ekonomiczna wskazuje na eksport jako na czynnik przyspieszenia wzrostu gospodarczego. $\mathrm{Z}$ drugiej strony liczne prace podnoszą problem możliwości wystapienia odwrotnego kierunku relacji przyczynowej - od wzrostu gospodarczego do rozwoju eksportu. Drugi kierunek zależności oznacza, że to rosnący wzrost gospodarczy wyzwala dynamikę eksportu.

Tradycyjne teorie handlu nie uwzględniały $\mathrm{w}$ stopniu dostatecznym zachowań przedsiębiorstw i ich wpływu na kształt międzynarodowej wymiany ekonomicznej. Nowsze nurty teoretyczne handlu międzynarodowego zwracają swe zainteresowania ku mikroekonomicznym podstawom wymiany międzynarodowej. Szczególnym przedmiotem zainteresowania nowych kierunków teorii jest wpływ zróżnicowania przedsiębiorstw na kierunki, strukturę i wielkość strumieni handlu. Zwrócenie się teorii handlu ku analizie międzynarodowej wymiany ekonomicznej z perspektywy mikroekonomicznej urealnia rozważania teoretyczne. Badania takie nabierają jednocześnie charakteru sektorowego, podczas gdy teoria klasyczna i neoklasyczna koncentruje się na poziomie państw. Dodatkowo, przejście na mikroekonomiczny poziom analizy handlu międzynarodowego rodzi dalekosiężne implikacje dla polityki gospodarczej.

\section{Cel i metody badań}

Celem opracowania jest analiza współzależności między międzynarodową wymianą produktami rolno-żywnościowymi a poziomem produkcji rolnej w wybranych krajach Unii Europejskiej. Do analizy wytypowano sektory rolne Polski i Francji ze względu na skrajnie odmienny charakter powiązań produkcji rolnej $\mathrm{z}$ wymianą zagraniczną towarami 
bazującymi na surowcach rolnych. Określenia używane w dalszej części opracowania jak „eksport” bądź ,import” dotyczą wyłącznie produktów wytwarzanych w oparciu o surowce rolne. Termin „,produkcja” odnosi się do produkcji brutto sektora rolnego danego kraju. Badanie oparto o dane bazy statystycznej FAO (FAOSTAT 2016). Dane źródłowe mają charakter roczny w ujęciu wartościowym (USD), a analiza dotyczy lat 1991-2013.

Badanie relacji między poziomami eksportu i produkcji rolnej oparto o metodologię analizy kointegracyjnej. Do weryfikacji hipotezy o współzależności rozpatrywanych procesów wykorzystano modele wektorowej autoregresji (VAR). Uwag odnośnie właściwości metodologii VAR z perspektywy zastosowań do analizy problemów ekonomicznych można poszukiwać w pracach, na przykład: Bernanke (1986) bądź Blancharda i Watsona (1986). Szersze omówienie własności modelowania zagadnień ekonomicznych z wykorzystaniem modeli VAR dostępne jest między innymi w opracowaniach Charemzy i Deadmana (1992) oraz Endersa (1995). Statystyczne własności modeli VAR obszernie omawiają Johansen (1995) oraz Lütkepohl (1991).

Przyjmuje się, że wersje długookresowe modeli ekonomicznych odpowiadają stanowi stacjonarnemu, a do reprezentacji stanu równowagi długookresowej można użyć równanie relacji kointegracyjnej. Stąd do oceny skointegrowania badanych relacji wykorzystano metodę Johansena (1988). Johansen w badaniu charakteru związku między zmiennymi oparł się na modelu VAR, który w formie zwartej można zapisać jako:

$$
x_{t}=A_{0} D_{t}+\sum_{i=1}^{k} A_{k} x_{t-k}+e_{t}, \quad t=1,2, \ldots, T
$$

gdzie:

$x_{t}-$ wektor obserwacji na wartościach $n$ zmiennych modelu $x_{t}=\left[x_{1 t} x_{2 t} \ldots, x_{n t}\right]^{\prime}$,

$D_{t}$ - wektor deterministycznych składników równań (wyraz wolny, zmienna czasowa, itp.),

$A_{0}$ - macierz parametrów przy zmiennych wektora $D_{t}$,

$A_{i}$ - macierze parametrów przy opóźnionych zmiennych wektora $x_{t}$ (nie zawierają elementów zerowych),

$e_{t} \quad$ - wektory stacjonarnych zakłóceń losowych: $e_{t}=\left[e_{1 t} e_{2 t} \ldots, e_{n t}\right]^{\prime}$.

Testowanie skointegrowania zmiennych metodą Johansena wiąże się z przekształceniem modelu VAR do postaci modelu korekty błędem (VECM):

$$
\Delta x_{t}=\Psi_{0} D_{t}+\Pi x_{t-1}+\sum_{i=1}^{k-1} \Pi_{i} \Delta x_{t-i}+\epsilon_{t}
$$

gdzie: $\Pi=\sum_{i=1}^{k} A_{i}-I, \Pi_{i}=-\sum_{j=i+1}^{k} A_{j}$.

Johansen odwołując się do równania (2) zaproponował wykorzystanie rzędu macierzy $\Pi$ do oceny charakteru związku między zmiennymi. Rząd macierzy $\Pi$ jest równy liczbie niezależnych wektorów kointegrujących. 
Oceny stacjonarności zmiennych użytych w badaniu dokonano poprzez weryfikację hipotezy o występowaniu pierwiastków jednostkowych w oparciu o test KwiatkowskiegoPhillipsa-Schmidta-Shina (KPSS) (Kwiatkowski „i in.”, 1992).

\section{Hipoteza wzrostu gospodarczego stymulowanego przez eksport a założenie o endogeniczności wzrostu}

Współzależności między handlem zagranicznym i rozwojem gospodarczym były przedmiotem zainteresowania badaczy od ukazania się pierwszych kompleksowych analiz ekonomicznych (Chen, 2009). Literatura przywołuje przykłady w tym zakresie - na ogół bez odpowiedniego potwierdzenia $w$ faktach i uzasadnienia teoretycznego. We współczesnej literaturze eksport zyskał miano jednego z najistotniejszych bezpośrednich czynników stymulacji tempa wzrostu gospodarczego. Podkreśla się również pośredni wpływ eksportu na perspektywy rozwoju ekonomicznego, który objawia się poprzez zwiększenie inwestycji w gospodarce oraz wzrost wydajności pracy. De Melo i Robinson (1990) przypisują udziałowi w handlu międzynarodowym dodatkowe pozytywne efekty zewnętrzne, jak korzyści skali, realokację zasobów i efekty uczenia się. Krugman (1997) podkreśla dwa aspekty oddziaływania handlu zagranicznego na wzrost gospodarczy optymalizację alokacji zasobów między sektorami produkcji i wiedzy technicznej oraz możliwość osiągania korzyści skali.

Intensywna rywalizacja na rynku międzynarodowym, który wyróżnia się na ogół wyższym poziomem konkurencyjności niż rynki krajowe, wymusza na przedsiębiorstwach osiagganie coraz wyższych poziomów efektywności funkcjonowania. Dodatkowo, rynki zagraniczne stawiają wysokie bariery wejścia - stąd warunkiem ulokowania produktu jest zwykle zademonstrowanie wysokiego poziomu innowacyjności opartego na unikalnej technologii. W następstwie intensywnej rywalizacji konkurencyjnej na rynku międzynarodowym dochodzi do rugowania z niego przedsiębiorstw najmniej efektywnych. Z tego tytułu pozostałe przedsiębiorstwa zwykle osiagają marże i zyski wyższe niż ogół podmiotów aktywnych $\mathrm{w}$ danej gałęzi. Wymagający rynek międzynarodowy jest dla przedsiębiorstw źródłem wielu nowych idei, nowych technologii oraz wzorców dla nowych produktów i rozwiązań organizacyjnych. Długookresowo efekty rozlania postępu technicznego, którego inicjatorami są przedsiębiorstwa eksportujące można obserwować w całej gospodarce.

Lata 80-te ubiegłego wieku zapoczątkowały okres dynamicznego rozwoju teorii wzrostu gospodarczego. Podwaliny współczesnej teorii wzrostu stworzyły w szczególności prace takich autorów jak: Romer (1986, 1990, 1994), Lucas (1988), Mankiw, Romer i Weil (1992), Barro i Sala-i-Martin (1995). Współcześni autorzy wiążą wzrost gospodarczy w krajach wysoko rozwiniętych ze wzrostem wydajności czynników produkcji. Nowoczesna teoria wzrostu poszukuje źródeł wzrostu wydajności czynników produkcji w postępie technicznym. Długookresowo, zadaniem handlu międzynarodowego jest wspieranie wzrostu gospodarczego dzięki rozprzestrzenianiu się technologii w wyniku jej przepływu z krajów bardziej zawansowanych oraz poprzez efekt zewnętrznej stymulacji wynikający z presji konkurencyjnej i intensywnej wymiany informacji między krajami.

W literaturze powszechną akceptację znajduje hipoteza o możliwości pobudzania wzrostu gospodarczego przez rozwój eksportu. Hipoteza ta zakłada, że eksport w sprzyjających okolicznościach może stać się czynnikiem stymulacji rozwoju 
gospodarczego. Ściślej, hipoteza o dynamizacji tempa wzrostu gospodarczego przez eksport wiąże bezpośrednio politykę rozwoju eksportu z efektami ekonomicznymi. Stosownie do tej koncepcji odpowiednio realizowana polityka pobudzania eksportu staje się czynnikiem przyspieszenia tempa wzrostu gospodarczego lub osłabienia jego spadku.

Procesy obserwowane $\mathrm{w}$ realnym świecie mogą jednak znacząco odbiegać od ich teoretycznych uogólnień. Złożoność relacji ekonomicznych, wpływ dodatkowych czynników powoduje, że rzeczywiste współzależności między poziomem eksportu i tempem wzrostu gospodarczego mogą mieć charakter dwukierunkowy lub nawet sprzężenia zwrotnego. Teoria handlu nie wyjaśnia jednoznacznie charakteru zależności między eksportem i wzrostem gospodarczym oraz nie thumaczy wystarczająco przyczynowości $\mathrm{w}$ tej relacji. $\mathrm{Z}$ drugiej strony wspominane współzależności są przedmiotem licznych analiz empirycznych. Giles i Williams (2000) zauważają że badania w tym zakresie prowadzone są najczęściej z wykorzystaniem technik analizy szeregów czasowych, rzadziej opierają się na danych przekrojowych, a nowsze opracowania odwołują się częściej do analizy metodą kointegracyjną.

Nurt wykorzystujący techniki analizy szeregów czasowych do badania relacji między eksportem i wzrostem gospodarczym nie pozwala na identyfikację kierunku oddziaływania zależności przyczynowo-skutkowych. Przykładowo przedstawicielami tego ujęcia badawczego są Foster (2006), Ram (1987), Salvatore i Hatcher (1991), Sengupta (1993).

Badania dokonywane w oparciu o dane przekrojowe ze względu na własności danych nie pozwalają na ustanowienie zależności przyczynowych. Metodologia wykorzystuje modele oparte na metodzie najmniejszych kwadratów oraz analizy korelacyjne. Xu (1996) przeprowadzając badanie dla 32 krajów pozytywnie zweryfikował hipotezę o stymulacji wzrostu dla 17 państw, gdzie w 9 przypadkach zależność była bardzo silna. Także inni autorzy wykorzystujący tę metodologię, między innymi: Balassa (1977 i 1978), Feder (1982), Heller i Porter (1978), Kavoussi (1984), Kravis (1970), Tyler (1981) w ogólności wspierają pogląd o zależności między eksportem i wzrostem gospodarczym.

W większości wyniki badań empirycznych, które wykorzystują podejście kointegracyjne sugerują występowanie efektu przyspieszenia tempa wzrostu gospodarczego jako odpowiedzi na rozwój eksportu. Niektóre modele sugerują także możliwość występowania zależności dwukierunkowej. Przykładowe analizy oparte na metodzie kointegracyjnej to: Awokuse (2005), Balaguer i Cantavella-Jorda (2004), Dhawan i Biswal (2010), Islam (1998), Richards (2001), Siliverstovs i Herzer (2006), Thornton (1996). Niemniej, niektóre badania metodą kointegracyjną nie prowadzą do zdefiniowania żadnej formy współzależności między rozwojem eksportu i tempem wzrostu gospodarczego (Dutt i Ghosh, 1994; Shan i Sun, 1998).

Niektórzy badacze dodatkowo oprócz stymulacji wzrostu gospodarczego eksportem sygnalizują przeciwny kierunek zależności. Na przykład Bhagwati (1988) sugeruje, że w ekonomii powszechnie należy oczekiwać dwukierunkowego oddziaływania między eksportem i wzrostem gospodarczym. Obserwacje empiryczne prowadzą do konkluzji o wzroście gospodarczym wywodzonym z poprawy efektywności funkcjonowania, który wyzwala ekspansję eksportową. Jung i Marshall (1985) zakładają że wzrost gospodarczy jest oparty w tendencji endogenicznej i wskazują kierunek zależności od wzrostu do rozwoju eksportu. Koncepcję o priorytetowej roli wzrostu gospodarczego w stosunku do perspektyw wzrostu eksportu wspierają Helpman i Krugman (1985). Autorzy argumentują na rzecz nieodzowności ekspansji eksportowej wraz ze zwiększaniem się skali działalności przedsiębiorstw. Warunkiem osiągania profitów z efektów skali przy rosnącej produkcji 
jest pokonanie ograniczeń rynku krajowego. Venables (1996) uzasadnia pogląd o kierunku wpływu od wzrostu gospodarczego do eksportu faktem niepełnej konkurencji między gałęziami gospodarki oraz procesami integracji pionowej procesów produkcyjnych.

Henriques i Sadorsky (1996) w oparciu o model wektorowej autoregresji (VAR) dla gospodarki kanadyjskiej stwierdzili, że zmiany w PKB poprzedzają zmiany wartości eksportu. Al-Yousif (1999) w oparciu o model korekty błędem rozszerzył badanie poza tempo wzrostu PKB oraz eksportu o zmienne: indeks zatrudnienia, tworzenie kapitału oraz wskaźnik terms of trade i konkluduje:

- krótkookresowo - wyniki potwierdzają hipotezę o stymulacji wzrostu gospodarczego przez eksport,

- długookresowo - wzrost gospodarczy kształtuje się pod wpływem tendencji endogenicznej.

Badania sugeruja, że w długim okresie rosnący wzrost gospodarczy dynamizuje eksport.

Wśród badaczy wzrostu gospodarczego przedmiotem debaty jest fakt i przyczyny wyraźnego zróżnicowania tempa zjawiska pomiędzy różnymi krajami. Podnoszony jest problem celowości rozróżnienia zagadnienia między gospodarkami krajów rozwijających się oraz krajów rozwiniętych.

\section{Wyniki badań i dyskusja}

Hipoteza o stymulacyjnej roli eksportu w stosunku do produkcji rolnej zakłada determinację poziomu produkcji wielkością eksportu. Według tej hipotezy wzrost produkcji rolnictwa można osiagnąć poza innymi czynnikami poprzez rozwój eksportu towarów bazujących na surowcach rolnych. Stąd eksport może pełnić rolę czynnika stymulacji produkcji rolnej. Natomiast hipoteza o zmianach produkcji poprzedzających zmiany eksportu zakłada przeciwny kierunek wpływu. Próby kwantyfikacji relacji między eksportem i produkcją rolną dokonano dla dwóch wybranych krajów Unii Europejskiej Polski i Francji. Motywem doboru podmiotów analizy były skrajnie odmienne typy współzależności.

Tabela 1. Wyniki testów stacjonarności na podstawie testu KPSS (Polska)

Table 1. Outcome of stationarity tests based on KPSS test (Poland)

\begin{tabular}{l|cccc}
\hline \multirow{2}{*}{ Zmienna } & \multicolumn{2}{|c}{ Poziomy zmiennych } & \multicolumn{2}{c}{ Pierwsze różnice } \\
& Statystyka testu & $\mathrm{p}$ & Statystyka testu & $\mathrm{p}$ \\
\hline produkcja $(\mathrm{p})-\mathrm{z}$ trendem & 0,2029 & $\mathrm{p}=0,013$ & 0,0468 & $\mathrm{p}>0,1$ \\
eksport $(\mathrm{e})-\mathrm{z}$ trendem & 0,3044 & $\mathrm{p}<0,01$ & 0,0759 & $\mathrm{p}>0,1$ \\
eksport netto $(\mathrm{n})-\mathrm{z}$ trendem & 0,2500 & $\mathrm{p}<0,01$ & 0,0682 & $\mathrm{p}>0,1$ \\
\hline
\end{tabular}

Źródło: opracowanie własne na podstawie: FAOSTAT 2016.

Modelowanie związków między produkcją rolną i wymianą zagraniczną produktami polskiego sektora rolnego dokonano w oparciu o zmienne produkcja (p), eksport (e) oraz import (i) produktów rolno-spożywczych. Oceny charakteru procesów generujących zmienne dokonano $\mathrm{z}$ wykorzystaniem testu KPSS. Wyniki testów stacjonarności przedstawiono $\mathrm{w}$ tabeli 1. Hipoteza zerowa $\mathrm{w}$ teście KPSS zakłada stacjonarność zmiennych. Dla zmiennych w postaci oryginalnej statystyki testowe większe od wartości 
krytycznych prowadzą do odrzucenia hipotezy o stacjonarności. Po przekształceniu przez różnicowanie zmienne satysfakcjonują warunek stacjonarności $(p>0,1)$.

Oceny charakteru relacji między poziomem produkcji rolnictwa polskiego oraz wymianą handlową $\mathrm{z}$ zagranicą towarami bazującymi na surowcach rolnych dokonano metodą Johansena. W tablicy 2 przedstawiono wyniki testu kointegracji dla zmiennych: produkcja $(p)$ oraz eksport $(e)$ z trendem oraz stałą poza relacją kointegracyjną. Wyniki testu kointegracji wskazują na zerowy rząd macierzy $\Pi\left(\lambda_{\text {rrace }}=11,7010 p=0,3379\right.$; $\left.\lambda_{\max }=11,0760 p=0,3113\right)$. Zerowy rząd macierzy $\Pi$ oznacza, że do opisu badanych relacji należy wykorzystać model VAR dla przyrostów zmiennych w postaci równania (1).

Tabela 2. Badanie kointegracji zmiennych: produkcja rolna $(p)$ oraz eksport produktów rolno-żywnościowych $(e)$ - test Johansena (Polska)

Table 2. Examination of cointegration of variables: agricultural production $(p)$ and agricultural exports $(e)-$ Johansen test (Poland)

\begin{tabular}{c|cccrc}
\hline \multirow{2}{*}{ Rząd macierzy } & Wartość własna & $\lambda_{\text {trace }}$ & $\mathrm{p}$ & $\lambda_{\max }$ & $\mathrm{p}$ \\
\hline 0 & 0,3955 & 11,7010 & 0,3379 & 11,0760 & 0,3113 \\
1 & 0,0280 & 0,6254 & 0,4290 & 0,6254 & 0,4290 \\
\hline
\end{tabular}

Źródło: opracowanie własne na podstawie: FAOSTAT 2016.

Dla projektowanego modelu VAR na podstawie odpowiednich testów i oceny własności modelu ustalono opóźnienie $k=1$. Dla przyjętego opóźnienia dokonano estymacji równań systemu, gdzie: $x_{t}=[\Delta p, \Delta e], D_{t}=[1, \Delta n, K r]$. W wektorze deterministycznych składników równań zawarto wyraz wolny (const) oraz zmienną pierwsze przyrosty eksportu netto $(\Delta n)$ i zmienną wprowadzającą korektę na skutki kryzysu finansowego z roku $2008(K r)$. Parametry dwurównaniowego modelu dla równania 1 zawiera tablica 3.a, natomiast oszacowania współczynników równania 2 zaprezentowano w tablicy 3.b. Ze względu na ograniczenia objętości opracowania nie przedstawiono wyników testów służących do oceny modelu. Niemniej, wszystkie podstawowe warunki metodologiczne zostały zachowane. Skutkiem, od strony formalnej model nadaje się do wykorzystania. Uzyskane rozwiązanie jest rozwiązaniem szczególnym systemu VAR, a elementy wektora $x_{t}$ są zbieżne. Między zmiennymi systemu VAR zachodzi silna relacja (wartość skorelowania z macierzy wariancji i kowariancji dla reszt poszczególnych równań wynosi 0,732 ).

Oszacowany system równań VAR umożliwia testowanie następujących hipotez o interakcji między zmiennymi:

- równanie 1: $\Delta e \rightarrow \Delta p$ - przyrosty eksportu nie są przyczyną przyrostów produkcji,

- równanie $2: \Delta p \rightarrow \Delta e$ - przyrosty produkcji nie są przyczyną przyrostów eksportu.

W równaniu pierwszym $(\Delta p)$ test $F$ dla hipotezy o braku restrykcji pozytywnie weryfikuje tezę o wpływie opóźnień zmiennej zależnej na jej wartości bieżące $(F(1,16)=6,1161 p=0,0250)$. Test współzależności wskazuje także na istotny wpływ opóźnień przyrostów eksportu na kształtowanie się zmian produkcji $(F(1,16)=8,7975$ $p=0,0091)$. W równaniu występuje składnik deterministyczny stała (const) oraz dwie istotne statystycznie zmienne egzogeniczne: przyrosty eksportu netto $(\Delta n)$ i zmienna $K r$.

W równaniu drugim opisującym przyrosty eksportu $(\Delta e)$ test $F$ dla hipotezy o braku restrykcji nie prowadzi do odrzucenia hipotezy o nieistotności opóźnień zmiennej $\Delta p$ na 
bieżące wartości zmiennej zależnej $(F(1,16)=2,1664 p=0,1605)$. Przyrosty eksportu $(\Delta e)$ są kształtowane głównie przez własną tendencję rozwojową wobec istotności tej zmiennej w teście $F$ dla hipotezy o braku restrykcji $(F(1,16)=16,022 p=0,0010)$. Egzogeniczna zmienna przyrosty eksportu netto $(\Delta n)$ nie jest istotna statystycznie w tym równaniu.

Tabela 3.a. Oszacowania parametrów równania 1 modelu VAR: $\Delta p$ (Polska)

Table 3.a. Estimates of parameters of equation 1 of VAR model: $\Delta p$ (Poland)

\begin{tabular}{l|rrrc}
\hline \multicolumn{1}{c|}{ Zmienna } & Współczynnik & Błąd standardowy & $\mathrm{t}$ - Studenta & Wartość p \\
\hline const & 185,9680 & 424,4610 & 0,4381 & 0,6672 \\
$\Delta \mathrm{p}_{-} 1$ & $-0,5252$ & 0,2123 & $-2,4731$ & 0,0250 \\
$\Delta \mathrm{e}_{-} 1$ & 1,9392 & 0,6538 & 2,9661 & 0,0091 \\
$\Delta \mathrm{n}$ & $-1,8474$ & 0,6219 & $-2,9704$ & 0,0090 \\
$\mathrm{Kr}$ & $-8583,0800$ & 710,1340 & $-12,0866$ & 0,0000 \\
\hline
\end{tabular}

Źródło: opracowanie własne na podstawie: FAOSTAT 2016.

Tabela 3.b. Oszacowania parametrów równania 2 modelu VAR: $\Delta e$ (Polska)

Table 3.b. Estimates of parameters of equation 2 of VAR model: $\Delta e$ (Poland)

\begin{tabular}{l|rrrc}
\hline \multicolumn{1}{c|}{ Zmienna } & Współczynnik & Błąd standardowy & $\mathrm{t}$ - Studenta & Wartość p \\
\hline const & 331,5850 & 154,8770 & 2,1410 & 0,0480 \\
$\Delta \mathrm{p}_{-} 1$ & $-0,1688$ & 0,1147 & $-1,4719$ & 0,1605 \\
$\Delta \mathrm{e}_{-} 1$ & 1,0740 & 0,2683 & 4,0027 & 0,0010 \\
$\Delta \mathrm{n}$ & 0,0253 & 0,3082 & 0,0823 & 0,9355 \\
$\mathrm{Kr}$ & $-3429,6200$ & 347,2320 & $-9,8770$ & 0,0000 \\
\hline
\end{tabular}

Źródło: opracowanie własne na podstawie: FAOSTAT 2016.

Współzależności w obrębie systemu VAR opisuje także funkcja odpowiedzi na impuls $(I R F)$, którą przedstawiono na rysunku 1. Przebieg funkcji $I R F$ dowodzi, że model VAR dla polskiego sektora rolno-żywnościowego charakteryzuje się zbieżnością oraz stabilnością. Dla obu zmiennych, które są źródłem zaburzenia wartość impulsu jest najwyższa w pierwszym i drugim roku, a następnie zanika w umiarkowanym tempie. Najszybciej wygasa efekt zmian produkcji na produkcję. Natomiast impuls z eksportu na produkcję jest utrzymywany na wysokim poziomie do trzeciego okresu. Odpowiedź eksportu na zaburzenie z obu zmiennych systemu VAR posiada nieco odmienny charakter. Efekt impulsu z produkcji wygasa w drugim okresie do połowy, a następnie wolno zanika. Skutki impulsu z $\Delta e$ na $\Delta e$ utrzymują się w funkcji IRF przez dwa okresy i wygasają szybciej niż efekty impulsu wyprowadzone ze zmiennej $\Delta p$.

W tabelach 4-6 przedstawiono wyniki modelowania relacji między produkcją rolną i wymianą towarową z zagranicą produktami rolno-spożywczymi sektora rolnego Francji. Badanie przeprowadzono dla 23 obserwacji (za lata 1991-2013). Procesy generujace zmienne wykorzystywane $\mathrm{w}$ badaniu cechuje zarówno tendencja rozwojowa, jak i pierwiastek stochastyczny. Wyniki formalnej weryfikacji stacjonarności testem KPSS zamieszczono $\mathrm{w}$ tablicy 4. Dla każdej ze zmiennych należy odrzucić hipotezy o stacjonarności dla powszechnie przyjętych poziomów istotności. Natomiast transformacja 
zmiennych przez różnicowanie prowadzi do spełnienia postulatu stacjonarności w przypadku wszystkich szeregów czasowych, co pozwala na kontynuowanie badania.
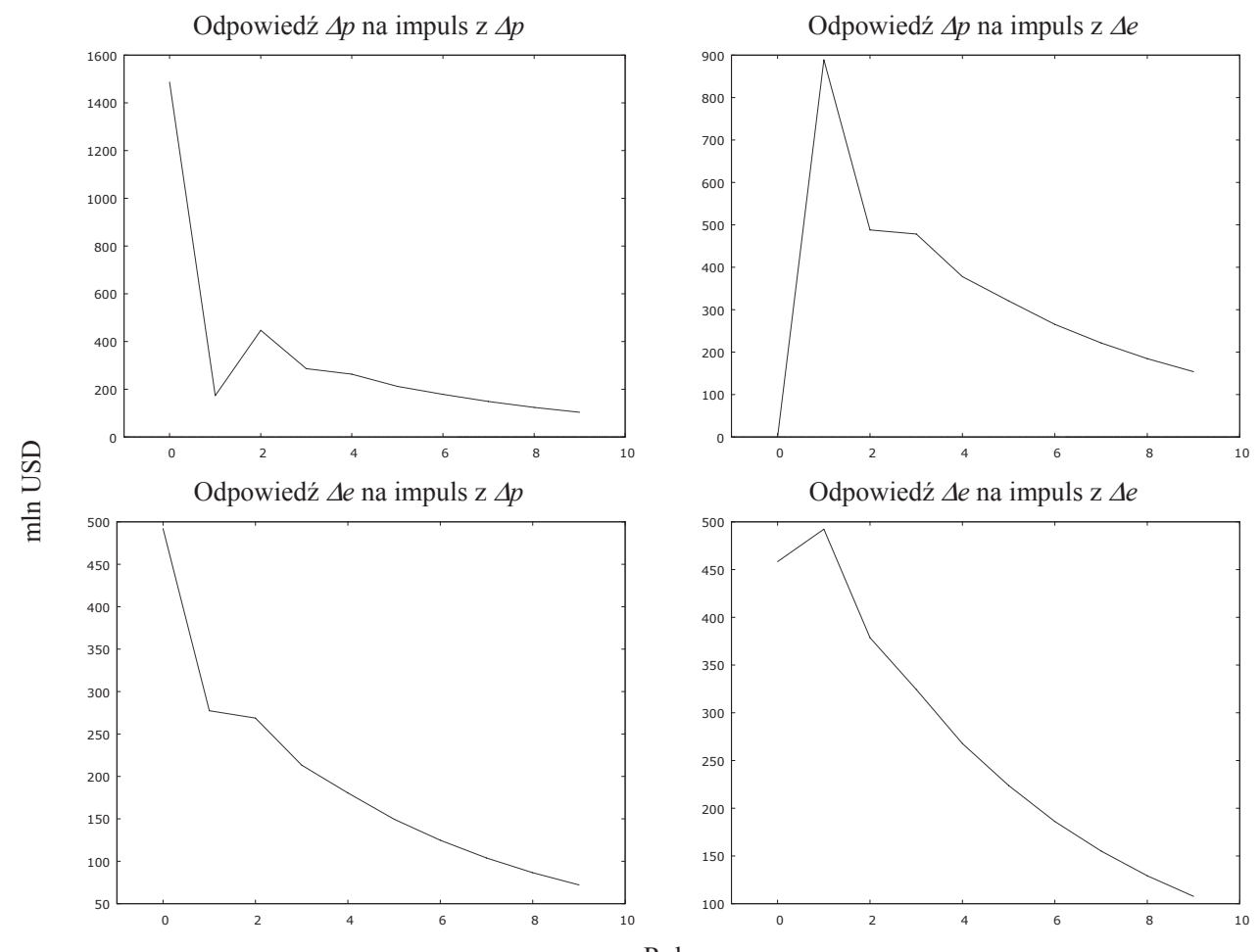

Rys. 1. Funkcja odpowiedzi na impuls w modelu VAR (Polska)

Fig. 1. Impulse response function for VAR model (Poland)

Źródło: opracowanie własne na podstawie: FAOSTAT 2016.

Tabela 4. Wyniki testów stacjonarności na podstawie testu KPSS (Francja)

Table 4. Outcome of stationarity tests based on KPSS test (France)

\begin{tabular}{l|cccc}
\hline \multicolumn{1}{c|}{ Zmienna } & \multicolumn{2}{|c}{ Poziomy zmiennych } & \multicolumn{2}{c}{ Pierwsze różnice } \\
& $\begin{array}{c}\text { Statystyka testu } / \\
\text { Test statistic }\end{array}$ & $\mathrm{p}$ & $\begin{array}{c}\text { Statystyka testu } / \\
\text { Test statistic }\end{array}$ & $\mathrm{p}$ \\
\hline produkcja $(\mathrm{p})-\mathrm{z}$ trendem & 0,2500 & $\mathrm{p}<0,01$ & 0,0485 & $\mathrm{p}>0,1$ \\
eksport $(\mathrm{e})-\mathrm{z}$ trendem & 0,2534 & $\mathrm{p}<0,01$ & 0,0480 & $\mathrm{p}>0,1$ \\
import (i) $-\mathrm{z}$ trendem & 0,2618 & $\mathrm{p}<0,01$ & 0,0591 & $\mathrm{p}>0,1$ \\
\hline
\end{tabular}

Źródło: opracowanie własne na podstawie: FAOSTAT 2016.

Oceny charakteru relacji między niestacjonarnymi zmiennymi dokonano $\mathrm{z}$ użyciem testu kointegracji Johansena. Po weryfikacji różnych konfiguracji, wyniki badania dla dwóch zmiennych: produkcja rolna $(p)$ oraz eksport produktów rolno-żywnościowych $(e)$ zaprezentowano w tablicy 5. Dla takiej struktury danych wartości statystyk testowych 
$\lambda_{\text {trace }}=7,4998(p=0,5273)$ oraz $\lambda_{\max }=7,4981(p=0,4408)$ prowadzą do utrzymania hipotezy o zerowym rzędzie macierzy $\Pi$. Brak niezależnych wektorów kointegrujących jest rekomendacją wykorzystania w analizie modelu VAR dla przyrostów zmiennych.

Tabela 5. Badanie kointegracji zmiennych: produkcja rolna $(p)$ oraz eksport produktów rolno-żywnościowych $(e)$ - test Johansena (Francja)

Table 5. Examination of cointegration of variables: agricultural production $(p)$ and agricultural exports $(e)-$ Johansen test (France)

\begin{tabular}{c|cccrc}
\hline \multirow{2}{*}{ Rząd macierzy } & Wartość własna & $\lambda_{\text {trace }}$ & $\mathrm{p}$ & $\lambda_{\max }$ & $\mathrm{p}$ \\
\hline 0 & & 7,4998 & 0,5273 & 7,4981 & 0,4408 \\
1 & 0,2888 & 0,0017 & 0,9669 & 0,0017 & 0,9669 \\
\hline
\end{tabular}

Źródło: opracowanie własne na podstawie: FAOSTAT 2016.

$\mathrm{Na}$ podstawie kryteriów informacyjnych: kryterium Schwartz-Bayesian $(B I C)$ oraz kryterium Hannan-Quinna $(H Q C)$ optymalną wartość opóźnienia dla projektowanego modelu VAR ustalono na $k=1$. Formalizację relacji między zmiennymi $\Delta p$ oraz $\Delta e$ dokonano w oparciu o system wektorowej autoregresji o postaci ogólnej (1), gdzie: $x_{t}=[\Delta p, \Delta e]$, natomiast $D_{t}=[1$, trend2000, $\Delta i]$. Oszacowania parametrów dwurównaniowego systemu VAR przedstawiono $\mathrm{w}$ tablicy 6a. oraz w tablicy $6 \mathrm{~b}$. Opracowany model poddano sprawdzeniu pod względem zgodności z założeniami metodologicznymi. Stosowne procedury testowe nie wskazały na naruszenie założeń metodologicznych, co przemawia za możliwością wykorzystania modelu do wnioskowania. System równań VAR cechuje się także stabilnością i zbieżnością. Wysoka wartość skorelowania zmiennych systemu (wartość z macierzy wariancji i kowariancji dla reszt równań) wynosząca $(0,670)$ wspiera tezę o silnym związku.

System równań VAR umożliwia testowanie następujących hipotez o interakcji między składowymi modelu:

- równanie 1: $\Delta e \rightarrow \Delta p$ - przyrosty eksportu nie są przyczyną przyrostów produkcji,

- równanie 2: $\Delta p \rightarrow \Delta e$ - przyrosty produkcji nie są przyczyną przyrostów eksportu.

W równaniu pierwszym opisującym kształtowanie się zmiennej $\Delta p$ test $F$ dla hipotezy o braku restrykcji nie wspiera tezy o wpływie opóźnień zmiennej objaśnianej na jej przyrosty $(F(1,16)=0,0655 p=0,8012)$. Test przyczynowości nie wskazuje także na zależność przyrostów produkcji od przeszłych wartości zmiennej $\Delta e(F(1,16)=0,0001$ $p=0,9922)$. Wysoce istotnym w równaniu jest składnik egzogeniczny przyrosty importu $(\Delta i)$. Dodatkowo do równania wprowadzono zmienną zerojedynkową trend2000, która wprowadza korektę na odmienne dynamiki składowych modelu przed i po roku 2000. Obecność tej zmiennej polepsza własności modelu.

Zależności opisywane w równaniu przyrostów eksportu ( $\Delta e)$ pozwoliły na zdefiniowanie ich w kategoriach przyczynowości. Test $F$ dla hipotezy o braku restrykcji prowadzi do utrzymania tezy o wpływie opóźnień zmiennej $\Delta e$ na jej wartości bieżące $(F(1,16)=5,9843 p=0,0264)$. Jednocześnie wysoce istotne dla kształtowania się zmiennej zależnej w równaniu 2 pozostają opóźnienia przyrostów produkcji $(F(1,16)=5,3536$ $p=0,0343)$. Dodatkowo istotnym jest czynnik egzogeniczny przyrosty importu $(\Delta i)$ oraz zmienna trend2000. Bazując na wynikach testu przyczynowości obu równań systemu VAR, 
można konkludować o wyższej priorytetowości produkcji w relacji do eksportu rolnospożywczego Francji. Umożliwia to określenie kierunku przyczynowości w postaci kształtowania eksportu przez produkcję rolną $(\Delta p \rightarrow \Delta e)$.

Tabela 6.a. Oszacowania parametrów równania 1 modelu VAR: $\Delta p$ (Francja)

Table 6.a. Estimates of parameters of equation 1 of VAR model: $\Delta p$ (France)

\begin{tabular}{l|rrrr}
\hline \multicolumn{1}{c|}{ Zmienna } & Współczynnik & Błąd standardowy & $\mathrm{t}$ - Studenta & Wartość $\mathrm{p}$ \\
\hline const & $-993,0300$ & 1529,5400 & $-0,6492$ & 0,5254 \\
$\Delta \mathrm{p}_{-} 1$ & $-0,0917$ & 0,3585 & $-0,2560$ & 0,8012 \\
$\Delta \mathrm{e}_{-} 1$ & $-0,0043$ & 0,4361 & $-0,0100$ & 0,9922 \\
trend2000 & $-113,0130$ & 1599,0100 & $-0,0707$ & 0,9445 \\
$\Delta \mathrm{i}$ & 1,2976 & 0,2190 & 5,9246 & $<0,0001$ \\
\hline
\end{tabular}

Źródło: opracowanie własne na podstawie: FAOSTAT 2016.

Tabela 6.b. Oszacowania parametrów równania 2 modelu VAR: $\Delta e$ (Francja)

Table 6.b. Estimates of parameters of equation 2 of VAR model: $\Delta e$ (France)

\begin{tabular}{l|rrrc}
\hline \multicolumn{1}{c|}{ Zmienna } & Współczynnik & Błąd standardowy & $\mathrm{t}$ - Studenta & Wartość $\mathrm{p}$ \\
\hline const & 244,8280 & 812,9370 & 0,3012 & 0,7672 \\
$\Delta \mathrm{p}_{-} 1$ & 0,4124 & 0,1782 & 2,3138 & 0,0343 \\
$\Delta \mathrm{e} \_1$ & $-0,4868$ & 0,1990 & $-2,4463$ & 0,0264 \\
trend2000 & 368,4220 & 872,5490 & 0,4222 & 0,6785 \\
$\Delta \mathrm{i}$ & 1,2535 & 0,1246 & 10,0590 & $<0,0001$ \\
\hline
\end{tabular}

Źródło: opracowanie własne na podstawie: FAOSTAT 2016

Opis wzajemnej relacji zmiennych systemu rozszerza badanie przebiegu funkcji odpowiedzi na impuls $(I R F)$. Dla francuskiego sektora rolnego wyniki analizy w formie graficznej przedstawiono na rysunku 2. Wykresy funkcji $I R F$ sugerują, że system dochodzi do równowagi w równaniu $1(\Delta p)$ tylko jeden rok po wystąpieniu zaburzenia w zmiennej $\Delta p$. Natomiast, przy zaburzeniu wywodzonemu z $\Delta e$ powrót do równowagi ze względu na zmienną $\Delta p$ trwa pięć okresów. W równaniu drugim efekt zaburzenia pochodzacy z obu zmiennych systemu utrzymuje się przez cztery okresy. Jednak w dwóch pierwszych okresach wyraźniejszy ślad pozostawia zaburzenie w zmiennej $\Delta p$.

W systemie VAR dla francuskiego sektora rolnego efekt impulsu $\mathrm{z}$ eksportu na produkcję jest minimalny. Największą wartość w systemie osiąga reakcja produkcji na impuls z produkcji. Najbardziej istotne są informacje odnośnie reakcji eksportu na impulsy ze strony zmiennych systemu $\mathrm{w}$ związku $\mathrm{z}$ wykryciem $\mathrm{w}$ równaniu drugim relacji przyczynowości. W tym równaniu impuls z produkcji na eksport jest podtrzymywany przez dwa okresy w stosunkowo wysokiej wartości. Natomiast stymulacyjna rola eksportu na eksport wygasa po jednym okresie. 
Odpowiedź $\Delta p$ na impuls z $\Delta p$

Variable $\Delta p$ response to $\Delta p$ impulse

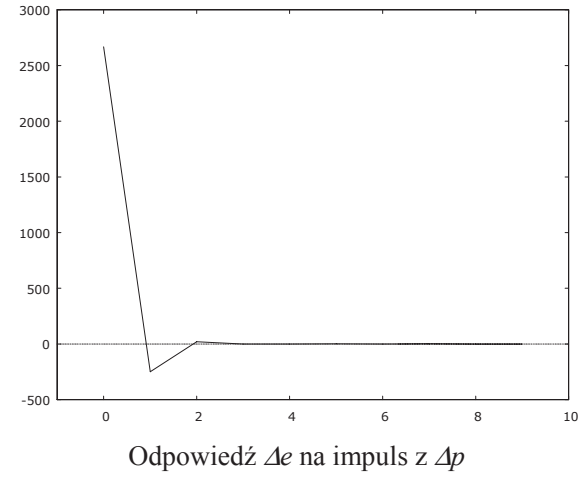

Variable $\Delta e$ response to $\Delta p$ impulse

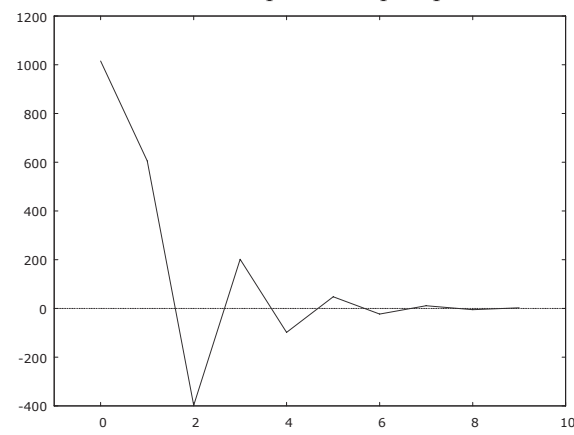

Odpowiedź $\Delta p$ na impuls z $\Delta e$ Variable $\Delta p$ response to $\Delta e$ impulse

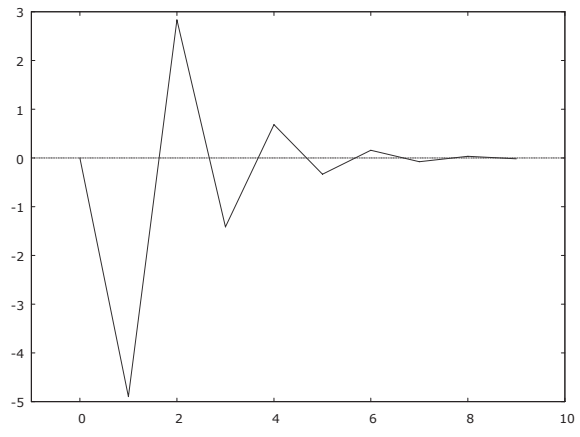

Odpowiedź $\Delta e$ na impuls z $\Delta e$ Variable $\Delta e$ response to $\Delta e$ impulse

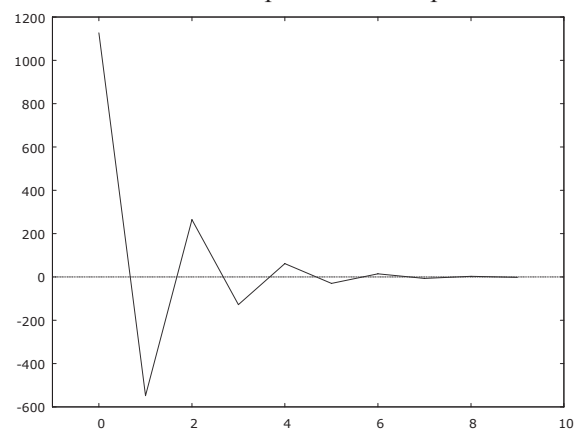

Rok / Year

Rys. 2. Funkcja odpowiedzi na impuls w modelu VAR (Francja)

Fig. 2. Impulse response function for VAR model (France)

Źródło: opracowanie własne na podstawie: FAOSTAT 2016.

\section{Podsumowanie}

Nie ograniczając wymiany handlowej z zagranicą do sfery polityki handlowej należy potraktować tę dziedzinę aktywności władz ekonomicznych państwa jako przejaw szeroko zakrojonej polityki gospodarczej zorientowanej na przyspieszenie wzrostu gospodarczego w pewnych wybranych sektorach gospodarki. Dalej, należy oczekiwać, że kompleksowa i spójna polityka gospodarcza w wyniku rozprzestrzeniania się impulsów wzrostowych na inne gałęzie umożliwi zdyskontowanie wzrostu wybranych sektorów przez całą gospodarkę.

Strategia wzrostu oparta na eksporcie była wdrażana przez wiele krajów. W literaturze można jednak obserwować zróżnicowanie poglądów na temat istoty wpływu eksportu na wzrost gospodarczy. Z jednej strony eksport postrzegany jest jako jeden z czynników stymulacji wzrostu gospodarczego. Niemniej, liczne opracowania empiryczne sugeruja odwrotny kierunek relacji - kształtowanie eksportu przez wzrost gospodarczy w miejsce 
dynamizacji wzrostu przez eksport. Charakter powiązań eksportu ze wzrostem gospodarczym wydaje się zależeć od horyzontu czasowego badania. Długofalowo eksport może być pochodną przyspieszonego tempa wzrostu gospodarczego. W przeciwieństwie do tradycyjnych teorii handlu międzynarodowego nowe nurty teoretyczne koncentrują swe zainteresowania na mikroekonomicznych podstawach wymiany międzynarodowej. Rozważania te nabierają charakteru sektorowego, co ma następstwa dla polityki gospodarczej.

Spoglądając z perspektywy sektorowej na znaczenie ekspansji eksportowej dla wzrostu produkcji rolnej i szans rozwojowych w rolnictwie, w świetle przeprowadzonych badań należy skonkludować o odmiennych rolach polityki gospodarczej związanej $\mathrm{z}$ międzynarodową wymianą towarową $\mathrm{w}$ poszczególnych krajach Unii Europejskiej. Analizę współzależności między poziomem produkcji rolnej i wymianą handlową $\mathrm{z}$ zagranicą towarami wytwarzanymi $\mathrm{w}$ oparciu o surowce rolne wykonano na podstawie metody kointegracyjnej i modeli wektorowej autoregresji (VAR).

Z przeprowadzonych badań wynika, że produkcja rolna w Polsce jest kształtowana w znacznej mierze poziomem eksportu, ale pozostaje także pod wpływem własnej tendencji rozwojowej. Dodatkowo, na poziom produkcji rolnej istotnie oddziałuje wielkość eksportu netto. Test przyczynowości doprowadził do odrzucenia hipotezy o wpływie zmian produkcji na eksport. Polski eksport rolno-spożywczy jest kształtowany w dużej mierze własną tendencją rozwojową. Eksport należy traktować jako czynnik „bardziej” endogeniczny, a produkcję jako czynnik „bardziej” egzogeniczny systemu VAR, co wspiera tezę o stymulacyjnej roli eksportu rolno-żywnościowego na produkcję sektora rolnego w Polsce.

Odmienny charakter współzależności zidentyfikowano dla francuskiego sektora rolnego. Test współzależności przeprowadzony dla równań systemu VAR nie pozwolił na ustalenie relacji współzależności między produkcją i eksportem oraz nie doprowadził do potwierdzenia wpływu opóźnień produkcji rolnej na jej aktualne wartości. Z drugiej strony zidentyfikowano zależność między bieżącymi i historycznymi wartościami eksportu rolnożywnościowego. Dodatkowo na kształtowanie się eksportu ma wpływ zmienna produkcja rolna. Stąd, test współzależności prowadzi do wniosku o wyższej priorytetowości produkcji w relacji do eksportu rolno-spożywczego Francji.

Wyniki obu modeli pozwalają wnioskować o odmienności relacji między poziomem produkcji rolnej a eksportem we Francji i w Polsce. W Polsce eksport wspiera produkcje rolną, a we Francji wysoki poziom produkcji sektora rolnego stymuluje eksport.

\section{Literatura}

Al-Yousif, Y.K. (1999). On the role of exports in the economic growth of Malaysia: A multivariate analysis. International Economic Journal, 13(3), 67-75.

Awokuse, T.O. (2005). Export-led growth and the Japanese economy: evidence from VAR and directed acyclic graphs. Applied Economics Letters, 12, 849-858.

Balaguer, J., Cantavella-Jorda, M. (2001). Examining the Export-Leg Growth Hypothesis for Spain in the Last Century. Applied Economics Letters, 8(10), 681-685.

Balassa, B. (1977). Export Incentives and Export Performance in Developing Countries: A Comparative Analysis, World Bank Staff Working Paper No. 248, Washington DC.

Balassa, B. (1978). Exports and economic growth: further evidence. Journal of Development Economics, 5 , 181-189.

Barro, R., Sala-i-Martin, X. (1995). Economic growth. McGraw-Hill, New York. 
Bernanke, B.S. (1986). Alternative Explanations for the Money-Income Correlation, W: K. Brunner, A. Meltzer (red.), Carnegie-Rochester Conference Series on Public Policy, North-Holland, Amsterdam.

Bhagwati, J. (1988). Protectionism, MIT Press, Cambridge, MA.

Blanchard, O., Watson, M.W. (1986). Are Business Cycles All Alike? W: The American Business Cycle: Continuity and Change, R.J. Gordon (red.), University of Chicago Press, Chicago.

Charemza, W.W., Deadman, D.A. (1992). New Directions in Econometric Practice, Edward Elgar, Hants.

Chen, H. (2009). A Literature Review on the Relationship between Foreign Trade and Economic Growth. International Journal of Economics and Finance, 1(1), 127-130.

De Melo, J., Robinson, S. (1990). Productivity and Externalities, Models of Export-Led Growth, The World Bank Working Papers, No. 387, Washington DC.

Dhawan, U., Biswal, B. (2010). Re-examining export-led growth hypothesis: a multivariate cointegration analysis for India. Applied Economics, 31(4), 525-530.

Dutt, S.D., Ghosh, D. (1994). An empirical investigation of the export growth - economic growth relationship. Applied Economics Letters, 1(3), 44-48.

Enders, W. (1995). Applied Econometric Time Series, John Wiley \& Sons, Inc., New York.

Feder, G. (1982). On export and economic growth. Journal of Development Economics, 12, 59-73.

Foster, N. (2006). Exports, growth and threshold effects in Africa. Journal of Development Studies, 42(6), 1056-1074.

Giles, J.A., Williams, C.L. (2000). Export-led Growth: a Survey of the Empirical Literature and some NonCausality Results. Journal of International Trade and Economic Development, 9, 261-337.

Heller, P.S., Porter, R.C. (1978). Exports and growth: An empirical re-investigation. Journal of Development Economics, 5, 191-193.

Helpman, E., Krugman, P.R. (1985). Market Structure and Foreign Trade. Increasing Returns, Imperfect Competition, and International Economy, The MIT Press, Cambridge, MA.

Henriques, I., Sadorsky, P. (1996). Export-led growth or growth-driven export? Canadian Journal of Economics, 29(3), 540-555.

Islam, M.N. (1998). Exports expansion and Economic growth; Testing for cointegration and causality. Applied Economics, 30, 415-425.

Johansen, S. (1995). Likelihood-Based Inference in Cointegrated Vector Autoregressive Models, Oxford University Press, New York

Johansen, S. (1988). Statistical Analysis of Cointegration Vectors. Journal of Economic Dynamics and Control, 12, 231-254.

Jung, S.W., Marshall, P.J. (1985). Exports, growth and causality in developing countries, Journal of Development Economics, 18, 1-12.

Kavoussi, R.M. (1984). Export expansion and economic growth: Further empirical Evidence. Journal of Development Economics, 14, 241-250.

Kravis, I.B. (1970). Trade as handmaiden of growth: similarities between the nineteenth and twentieth centuries. Economic Journal, 80, 850-872.

Krugman, P. (1997). Międzynarodowe stosunki gospodarcze. Teoria i polityka (International economic relations. Theory and politics), PWN, Warszawa.

Kwiatkowski, D., Phillips, P.C.B., Schmidt, P., Shin, Y. (1992). Testing the Null Hypothesis of Stationarity against the Alternative of a Unit Root. Journal of Econometrics, 54, 159-178.

Lucas, E. (1988). On the mechanics of economic development. Journal of Monetary Economics, 22(1), 3-42.

Lütkepohl, H. (1991). Introduction to Multiple Time Series Analysis, Springer-Verlag, Berlin-Heidelberg.

Mankiw, N.G., Romer, D., Weil, D. (1992). A contribution to the empirics of economic growth. Quarterly Journal of Economics, 107(2), 407-437.

Michałek, J.J. (2002). Polityka handlowa: mechanizmy ekonomiczne i regulacje międzynarodowe (Trade policy: economic mechanisms and international regulations), PWN, Warszawa.

Mundell, R. (1961). Flexible Exchange Rates and Employment Policy. Canadian Journal of Economics and Political Science, 27, 509-517.

Ram, R. (1987). Exports and Economic Growth in Developing Countries: Evidence from Time-Series and CrossSection Data. Economic Development and Cultural Change, 36(1), 51-72.

Richards, D.G. (2001). Exports as determinant of long-run growth in Paraguay, 1966-96. Journal of Development Studies, 38(1), 128-142.

Romer, P. (1986). Increasing returns and long-run growth. Journal of Political Economy, 94, 1002-1037.

Romer, P (1990). Endogenous technological change. Journal of Political Economy, 98, 71-102.

Romer, P. (1994). The origins of endogenous growth. Journal of Economic Perspectives, 8, 3-22.

Rosati, D. (1990). Polityka proeksportowa (Pro-export policy), PWE, Warszawa. 
Rynarzewski, T., Zielińska-Głębocka, A. (2006). Międzynarodowe stosunki gospodarcze. Teoria wymiany i polityki handlu międzynarodowego (International economic relations. The theory of exchange and international trade), PWN, Warszawa.

Salvatore, D., Hatcher, T. (1991). Inward and outward oriented trade strategies. Journal of Development Studies, $27,7-25$.

Sengupta, J.K. (1993). Growth in NICs in Asia: some tests of new growth theory. Journal of Development Studies, $29,342-357$

Shan, J., Sun, F. (1998). On the export-led growth hypothesis: The econometric evidence from China. Applied Economics, 30, 1055-1065.

Siliverstovs, B., Herzer, D. (2006). Export-led growth hypothesis: evidence for Chile. Applied Economics Letters, 13(5), 319-324.

Thornton, J. (1996). Cointegration, causality and export-led growth in Mexico, 1895-1992. Economics Letters, 50, 413-416.

Tyler, W. (1981). Growth and export expansion in developing countries: Some empirical evidence. Journal of Development Economics, 9, 121-130.

$\mathrm{Xu}, \mathrm{Z}$. (1996). On the causality between export growth and GDP growth: an empirical evidence. Review of International Economic, 4(6), 172-184

Venables, A. (1996). Equilibrium locations of vertically linked industries. International Economic Review, 37, 341-359.

Do cytowania / For citation:

Strojny J. (2018). Wzrost pobudzany eksportem czy eksport stymulowany wzrostem sektora rolnego. Problemy Rolnictwa Światowego, 18(1), 248-262; DOI: 10.22630/PRS.2018.18.1.23

Strojny J. (2018). Growth Led by Exports or Exports Driven by Agricultural Sector Growth (in Polish). Problems of World Agriculture, 18(1), 248-262; DOI: 10.22630/PRS.2018.18.1.23 